International Journal of Linguistics, Literature and Translation (IJLLT)

ISSN: 2617-0299 (Online); ISSN: 2708-0099 (Print)

DOI: $10.32996 / \mathrm{jjllt}$

Journal Homepage: www.al-kindipublisher.com/index.php/ijllt

IJLLT

\title{
My People, My Country: A New Interpretation of Chinese Main Melody Film in the New Era
}

Xu Xinyue ${ }^{1}$ and Hua Jing*2

${ }^{1}$ BA student of School of Foreign Languages, East China University of Science and Technology, Shanghai, China ${ }^{2}$ Associate Professor of School of Foreign Languages, East China University of Science and Technology, Shanghai, China

Corresponding Author: Hua Jing, E-mail: huajing0909@163.com

\section{ARTICLE INFORMATION}

Received: November 02, 2020

Accepted: December 05, 2020

Volume: 3

Issue: 12

DOI: $10.32996 /$ ijllt.2020.3.12.14

\section{KEYWORDS}

"My people, My country"; segmented structure;

fragmentation; individual values;

patriotism; film details

\section{ABSTRACT}

The Chinese film "My people, My country" runs through the historical process of the seventy years since the founding of New China. The film adopts a segmented narrative approach and successfully expresses the grand theme of national development through the stories of seven small characters. This paper provides a detailed analysis of "My people, My country" in terms of its narrative structure, narrative perspective and detail treatment. It is found out that the fragmented narratives, the individuals being the narrative center and the detailed historic setting in "My people, My country" all combined to offer a new interpretation for the main melody movies.

\section{Introduction}

"My people, My country" is an artistic reworking of the real historical events at seven important points in time since the founding of New China. The film tells the story of "the founding of the People's Republic of China", "the development of the atomic bomb", "the victory of the Chinese women's volleyball team", "the handover of Hong Kong to China", and "the development of the atomic bomb", "Beijing Olympic Games Successfully Held", "the successful landing of Shenzhou 11 Spacecraft ", "Military Parade to Commemorate the 70th Anniversary of the Victory of the War of Resistance" which revives the Chinese people's "common memory".

\section{2- Melodramatic films under fragmented narratives}

The film "My people, My country" adopts an innovative narrative structure. It is divided into seven units: "The Eve", "Passing By", "The Champion", "Going Home", "Hello Beijing", "The Guiding Star" and "One for all". Such a narrative structure is unprecedented in the field of melodrama films, and "My people, My country" opens up a new form of expression for melodrama films. "Through the linear linking of common themes, the film innovates the current mode of presentation of dedication films by offering artistic interpretation of the same theme through multi-viewpoint storytelling while retaining the individuality of each chapter's style. (Gao, 2020)." Starting with segmented narrative structure, in-depth analysis of the film "My people, My country" is of great value and has a constructive role in the innovation of the narrative mode of the main melody film in the new era.

The segmented film is divided into several parts according to different perspectives such as time, plot, objects and characters, and each part is a paragraph. From the perspective of time, the fragmented treatment of time in "My people, My country" is reflected in the explicit symbols of time decomposition (Tang, 2008). The film selects seven milestones in the history of China's development: the founding of New China in 1949, the successful explosion of China's first atomic bomb in 1964, the Chinese women's volleyball championship in 1984, Hong Kong's return to the motherland in 1997, the successful hosting of the 2008 Olympic Games, the military parade in 2015 to commemorate the 70th anniversary of the victory in the war, the 2016 Shenzhou 11 Spacecraft's landing. The seven "historical moments" corresponding to the successful landing of the ship

K C AL-KINDI CENTER
$\mathbf{R}$ D FOR RESEARCH AND
Your gateway to world-closs reiearch
Published by Al-KindiCenter for Research and Development. Copyright (c) the author(s). This is an open access article under CC BY license (https://creativecommons.org/licenses/by/4.0/) 
unfold chronologically. (Because the "One for all" unit ends with the 2017 Zhu Li He military parade of the 90th anniversary of the founding of the Chinese People's Liberation Army, it is ranked after "The Guiding Star.")

From a plot point of view, the plots of the seven units in the film "Me and My Country" are themselves independent of each other and not directly related. "The Eve" tells the story of the successful raising of the national flag on the eve of the founding ceremony in 1949, which marked China's formal establishment as an independent and sovereign state, thanks to the joint efforts of Lin Zhiyuan, the designer and installer of the electric flagpole, Lao Fang, the flag protector, and many staff and people. "Passing By" focuses on Gao Yuan, a researcher involved in the development of the atomic bomb, who has been out of touch with his family for three years and has fallen ill due to accidental exposure to nuclear radiation. He chooses between the love of his country and the love of his lover, and pays the price with his life. This story symbolizes the advancement of science and technology and the strengthening of China's national defense. "The Champion" depicts life in a Shanghai alleyway during the 1984 Olympic Games finals, where the people gather in front of a small television and a young man, Dong dong, has to adjust the antenna from time to time to find a signal. In front of the crowd, the Chinese women's volleyball team wins the championship, demonstrating the athletic prowess of Chinese athletes and proving the power of China to the world. "Going Home" tells the story of Hong Kong's return to the motherland on July 1, 1997. The efforts of flag-raisers Zhu Tao, Sister Lian, and diplomat An Wen bin to ensure that the five-star red flag was raised at 00:00 on July 1, pushed forward the process of reunification and proved that the country's strength had recently increased. Combining the events of the Wenchuan earthquake and the Beijing Olympics, "Hello Beijing" tells the story of a taxi driver, Zhang Beijing, and a boy from Wenchuan. Through a misunderstanding, he learns that the boy's father is an Olympic construction worker and decides to give the boy a valuable ticket to the opening ceremony of the Beijing Olympics. "The Guiding Star" correlates the era of precise poverty alleviation with the historical event of the successful landing of the Shenzhou 11 spacecraft in 2016, and tells the story of the dramatic changes that Wodler and Hazzab under the tutelage of Lao Li. They witness the successful landing of the Shenzhou 11 spacecraft - the "daytime meteor" - and develop a determination to work hard to build their hometown. The female pilot Lu Xiaoran in "One for all" was left as a replacement to deal with various emergencies due to her outstanding personal abilities on September 3, 2015, when the military parade commemorating the 70th anniversary of the victory of the war of resistance was held. As a "prepared flyer", she helped the team complete their flight mission and also fulfilled their mission.

Although the film adopts a fragmented narrative mode, its value construction is different from traditional segmented films. In segmented films, the film segments are composed of various links of events, and each link points to its own value, so there will be multiple value centers juxtaposed in the film, and the original center of the whole will be replaced by a fragmented platform (Tang, 2008). Throughout the film, one main thread runs through seven sections: the characters and the era, the era and the country (Shuai, 2019). Each section has its own value. Each paragraph has a consistent value core: patriotism, which achieves the effect of fragmentation.

Faced with this fragmented narrative pattern, the audience shows a high degree of acceptance. On the one hand, the segmented narrative structure has similarities and differences with the scattered perspective in Chinese painting ( $\mathrm{Yi}$, Huang \&Su, 2019). Scattered Perspective was originally a Chinese painting term, i.e., multi-point perspective, observing and tracing a certain thing from different angles, mobile and all-round, emphasizing the subject's and psychological reality (Liu \&Hou, 2009). As Ning Hao, one of the film's directors, once said: "In Chinese painting, Chinese landscape paintings are all scattered points, the mountains are not compatible with perspective at all, and neither is the river. Therefore, the Chinese psyche can accept these several points, this is part of the natural aesthetic of the Chinese audience. (Yin, Huang \& Su, 2019)." The film "My people, My country" is like a Chinese landscape painting, in which seven directors tell the events of Chinese history from their own life experiences, class, and thinking point of view, in a very personal way. Each unit is its own entity, with its own style, but at the same time, they are interconnected, forming the historical process of China's development for more than 70 years. In addition, the plot of the film is originally based on historical events that are well known to the Chinese people, so the audience is generally aware of the background and direction of the story, thus avoiding the confusion that a segmented narrative might cause to the audience. Therefore, in terms of aesthetic habits, Chinese audiences are quick to accept such a scattered and jumpy narrative mode.

On the other hand, the popularity of the short video industry in recent years has changed the consumption habits and aesthetic tendencies of viewers. According to the "2020 China Internet Audiovisual Development Research Report" released by China Internet Audiovisual Program Service Association, as of June 2020, the per capita single-day use of short video has reached 110 minutes; in the Internet audiovisual industry, the market size of short video accounted for the highest proportion, reaching 130.24 billion yuan, an increase of $178.8 \%$ year-on-year (Niu, 2020). In the "Tik Tok" platform, the average duration of a single video is less than 1 minute, and is filled with images of great visual impact. Under the influence of 
short videos, audiences tend to grow weary of traditional lengthy narratives and are more comfortable with short bursts of fragmented expression, making segmented episodes such as "My people, My country" a huge success in the new era, and since its release on October 1, 2019, it has grossed 3.102 billion at the domestic box office as of December 25 of the same year.

The popularity of "My people, My country" is initial proof of the viability of the fragmented treatment of melodramatic films and the importance of the fragmented aesthetic. Internationally, globalization has been shown to go hand in hand with fragmentation (so-called "non-homogeneous globalization") (Huang, 2013). As the process of globalization progresses, fragmentation will also become one of the directions for the development of melodrama films.

\section{3- Melodic Film with the Individuals as the Narrative Center}

Chinese President Xi Jinping has suggested that "the people are both the creators and witnesses of history, as well as the 'playwrights' of history. (Xi, 2017)" In the choice of narrative angle, "My people, My country" adheres to the creative guidance of "taking the people as the center" and "taking the people as the main body of literary and artistic expression (Ding, 2016)". As the main melody of the film, the film gives up the usual method of focusing on individual heroes and heroines, and instead expresses the grand theme of the development of the times through the stories of ordinary people, thus achieving the effect of "using the small to show the big".

In "The Eve", all thanks to the efforts of the main characters, including Lin Zhiyuan and the flag-bearer Lao Fang, the national flag was raised on time and the opening ceremony of the People's Republic of China goes off without a hitch. But the film also focuses on the contributions of more ordinary Beijing citizens. In order to ensure the accuracy of the electric flag raising, Lin had to build a model to one-third scale and repeatedly test it, but he encountered difficulties in recreating the same scale of the national flag and national anthem. The neighbors followed the loudspeaker's call and brought in their own metal products, carrying lanterns, when they needed chrome, nickel and silicon for the ball-breaker, the heart of the flagpole. Thus, the picture turns from darkness to light, and the eve of the founding ceremony is illuminated by thousands of lanterns. With the help of hundreds of ordinary people, the malfunction at the top of the national pole was solved and the five-star red flag was flown over Ti an men Square.

In "The Champion", Xu Zheng's film is set in the alleys of Shanghai. In Shanghai, Dong dong's family was the only one who owned a television, and he was the only one who knew how to fix the antenna. On the day of the Olympic women's volleyball final, the neighbors walked in the alley and gathered in front of a small black-and-white TV to watch the match; when the TV signal was abnormal, the residents took out their own semiconductors to follow the match. When the TV antenna was crooked and needed repair, Xiao Mei has also come downstairs, in the face of this very difficult choice, Dong dong chose to continue to maintain the position of the antenna, choose to give up a small personal love, the achievement of national love. This segment shows the brilliance of collectivism through the choices made by Dong dong, an ordinary boy, and the joy and glory of the Chinese people when the Chinese women's volleyball team won the championship through the ordinary residents of Shanghai's Shikumen.

Zhang Beijing in the unit "Hello Beijing" is an extremely ordinary Beijing citizen. He is a slightly negligent father who can't remember his son's shoe size; he is a mercenary taxi driver who, when he gets tickets to the opening ceremony of the Olympic Games, shows them off to satisfy his own vanity. When he met the Wenchuan boy and learned about his experience, he chose to give the precious tickets to the boy even though he was reluctant to give them to Beijing, showing the brilliance of human nature.

The reason why the film touches the audience is that it truly shows the reasonableness and vividness of individual emotions, demands and interests in the face of national interests, and the struggle and hardship of making choices between the state, the collective and the individual (Douban, 2019). The main melody of the film can only be more realistic and resonate with the audience if it establishes a full and three-dimensional image of ordinary people and cares about the value of individual lives under a grand narrative (Wang, 2020).

\section{4- The indispensable detailed historic setting for a melodrama}

Movies use moving images as the base means of expression, and detailing is an important factor that constitutes the pictorial image of the movie, which adds endless charm to the movie art (Xu, 1994). In the film "My people, My country", many aspects of details play a very important role.

Among all the details of the film, the details of the characters are of paramount importance (Zhang, 2007). People are the main body of the film, and they are the important embodiment of the theme. The detailed depiction of the characters' external and internal actions plays an important role in promoting the story plot and rendering the atmosphere of the story 
to a certain extent. In the first half of "The Eve", the movie gives a hint about Lin Zhiyuan's fear of heights. In the final moments before the opening ceremony begins, only Lin Zhiyuan can complete the task of climbing the flagpole to weld the blocking ball, and Lin's fear of heights adds to the difficulty of this already daunting task. This detail creates an atmosphere of tension and suspense: can Lin Zhiyuan really complete the task? Every move he made on the flagpole of the national flag touched the hearts of every audience. When he finally overcomes the huge physical and mental obstacles and successfully completes the welding, this detail further highlights his willpower and determination to dedicate himself to his country. The Passing By is set up with a number of details about researcher Gao Yuan, whose inner activities are constantly changing as events unfold. After being exposed to radiation through an accident, Gao Yuan knows that the irreversible damage will take his life. Faced with this fact, he appeared to be particularly calm, because when he chose to join the atomic bomb research and development business, he had already made up his mind that "his seven-foot body has been wholly devoted to the country". In his last days, he was always most concerned about the development of the atomic bomb. He repeatedly asked, "Are there any activities taking place in the streets?" He always pays attention to the newspaper, expecting to hear about the success of the atomic bomb, which is his last hope and the "last leaf" that sustains him. Afterwards, he ran into Fang Min, his lover of three years ago. At first, he is reluctant to meet Fang Min, because on the one hand, he has to keep the secret of the successful explosion of the first atomic bomb, and on the other hand, Gao Yuan thinks that his time is running out and does not want to add to his grief. However, as Fang Min recalls their past, Gao Yuan is moved. Eventually, the news of the successful explosion of the first atomic bomb arrives, and Gao Yuan has completed his mission.

As the object details of the props, it has a significant role in showing the personality of the characters, rendering the atmosphere of life and reflecting the atmosphere of the times (Xu, 1994). ${ }^{[14]}$ In the seven units of the film, each story begins with a writing scene, and each uses a different writing instrument. Brush pen in "The Eve", Hero 240 fountain pen in "Passing By", colored pencil in "The Champion", Parker IM fountain pen in "Going Home", Pelikan Golden Turtle fountain pen in "Hello Beijing", pencil in "The Guiding Star", and Baile Qian Yang fountain pen in "One for all" (Zhihu, 2019). Different writing instruments represent different eras, and the content of the writing also foreshadows the plot of the corresponding fragments. "Metaphors for the stories of 'me' and 'my motherland' in different eras (Duan, 2019)."

Analyzed at the audiovisual level, the sound details in "My people, My country" reveal the social background and the theme of the times, prompting the audience to fully integrate into the story. The aural focal details are mainly in the form of speech (dialogue, monologue, narration), music (music with and without sound source) and sound (ambient and artificial sound). Auditory focal details are mainly carried by three specific sound types: speech (dialogue, monologue, and narration), music (music with and without sound sources), and sound (ambient sound and artificial sound) (Zhang, 2007). The background wind sound in "The Eve" when Lin Zhiyuan climbs the national flag pole gives the audience a sense of being there, which helps to strengthen the audience's sense of substitution and create a tense atmosphere. The ticking of the clock in "Going Home" symbolizes time, and accurate timing is the most important part of the handover ceremony of Hong Kong. At the end of the clip, the song "Pearl of the Orient" echoes across Hong Kong, evoking a common memory of the handover. In the film, sound samples of each event are used as voice-overs, such as the audio of the news broadcast of the Founding Ceremony, the sports commentary of the women's volleyball team's championship, and Prince Charles' speech during the handover ceremony of Hong Kong. These recordings provide the audience with a stronger sense of presence (Shuai, 2019). In addition, the song "My people, My country" appears at the beginning and end of the film, forming a coherent echo, which plays a role in highlighting the theme and rendering patriotic sentiments.

\section{5- Conclusion}

As a main melody movie, "My people, My country" conforms to no conventional pattern. Unlike other films of its type, it adopts a segmented narrative structure and a personal narrative perspective to tell the Chinese historical events in a clear and orderly way. Also, a few national elements are added to detail treatment which make the film more realistic and immersive. Through a comprehensive analysis of "My people, My country", this paper reveals that the narrative structure, narrative perspective and detail treatment of this movie all contribute to its success. It offers new insight into the future making of main melody movies. Filmmakers should try to adopt creative narrative strategies and learn to combine national elements with contemporary characteristics as well. This may bring main melody movies closer to the audience, make it easier to understand thus attracting public attention and affection. This paper has mainly focused on the film "My people, My country" and further research is expected to carried out. And the research subjects are not limited to Chinese main melody movies but movies from all over the world. 
Acknowledgments: This paper is part of the achievement of the University Students Innovation Project of Shanghai in 2020, "Nationality and Cosmopolitanism of Film and Television Literature and its Cross-cultural Communication in the Context of Globalization" (S20107)

Conflicts of Interest: The authors declare no conflict of interest. "The funders had no role in the design of the study; in the collection, analyses, or interpretation of data; in the writing of the manuscript, or in the decision to publish the results".

\section{References}

[1] Ding G.Q. (2016). Socialist literature and art is the people's literature and art. Guang Ming Daily, 12-25(06).

[2] Duan Y.D. (2019). "My people, My country": writing the glory of the country and its people. People's Daily News, 12-02(012).

[3] Gao S. (2020). Narrative Thinking of Segmented Films from the Perspective of Multi-Directors-Taking the Film "My people, My country" as an Example. Modern Audiovisual, (03), 61-64.

[4] Huang M.F. (2013). Representation of fragment aesthetics in "ultra-modern". Academic Monthly, (06), 36-46. 10.

[5] Liu D.X \&Hou X.X. (2009). The Scattered Perspective of Humanistic Tradition. Art, (01), 27-32.

[6] "My people, My country": A Narrative of Nationalism and Collectivism from an Individual Perspective, https://movie.douban.com/review/10574532/

[7] Niu M.D. (2020). Why "Platter Films" are Popular. Guang Ming Daily, 2020-10-22. http://www.rmzxb.com.cn/c/2020-1022/2695260.shtml

[8] Shuai X.Y. (2019). Fragmented Narrative: “My people, My country". Nanfang Media College, 2019.10.3. https://mp.weixin.qq.com/s/dqSH0V3PUMgqfbGoaXX9wg

[9] Tang T.T. (2008). Towards the Integral Fragment-A Preliminary Exploration of Segmented Films. Fudan University

[10] Wang Z. (2020). Interview I Mastermind Zhang Yibai: "My people, My country" should reflect the same origin of family and country. Breaking News, 10-1. https://www.thepaper.cn/newsDetail_forward_9436704

[11] Xi J.P. (2017). Xi Jinping on Governance and Politics, Volume 2, Foreign Language Press, p314.

[12] Xu Y.H. (1994). On the Art of Detail in Film. Journal of Huzhou Normal College, (03),59-64.

[13] Yin H, Huang J \& Su Y. (2019). The National Memory and Emotional Collision of Historical Moments-Talking with Huang Jianxin about "My people, My country" and The Decisive Moment. Film Art, (06), 69-76.

[14] Zhang H.X. (2007). On the Narrative of Film and Television Details. Yunnan Normal University

[15] Inventory of the Fountain Pen Heroes in the Film "My people, My country". Parker, Pelikan, https://zhuanlan.zhihu.com/p/85243565. 